\title{
The collaborative interdependence in the local production arrangement of gems and jewels in South of Brazil
}

\section{Luiz Fernando Fritz Filho*}

University Passo Fundo (UPF),

Av. Major João Schell, 988,

Passo Fundo - Rio Grande do Sul, Brazil

Email: fritz@upf.br

*Corresponding author

\section{Anelise Rebelato Mozzato}

University Passo Fundo (UPF), Av. Adolfo Loureiro, 190/401, Lagoa do Potreiro - Passo Fundo, Rio Grande do Sul, Brazil

Email: anerebe@upf.br

\section{Karen Beltrame Becker Fritz}

University Passo Fundo (UPF),

Av. Major João Schell, 988,

Passo Fundo - Rio Grande do Sul, Brazil

Email: karenfritz@upf.br

\begin{abstract}
This research aims to understand the inter-organisational relations (RIOs) in the local productive arrangement (LPA) of gems and jewels of the South of Brazil, analysing to what extent the prevalence of characteristics of collaborative interdependence occurs. The paper addresses questions about developing LPAs, followed by the centralised discussion on the importance of the presence of collaborative interdependence between the different actors in RIOs. This exploratory research is characterised as a qualitative case study. The data collection was done through interviews, non-participant observation, and documentary analysis. Content analysis was adopted as a data analysis technique. The results indicate the occurrence of collaborative interdependence between the different actors that maintain RIOs. Collaboration on actions related to shared goals, use of common resources and complementarity of tasks is confirmed. However, it is also evidenced that the collaborative interdependence can be more effective, covering the LPA.
\end{abstract}

Keywords: local productive arrangements; LPAs; collaborative interdependence; inter-organisational relations; gems and jewels; network; spatial agglomeration; collaborative relations; developing country; interdependence; South of Brazil. 
Reference to this paper should be made as follows: Fritz Filho, L.F., Mozzato, A.R. and Becker Fritz, K.B. (2019) 'The collaborative interdependence in the local production arrangement of gems and jewels in South of Brazil', Int. J. Strategic Business Alliances, Vol. 6, No. 4, pp.233-250.

Biographical notes: Luiz Fernando Fritz Filho holds a Doctor's degree in Rural Development at the UFRGS University, Brazil. He is a Professor at the University of Passo Fundo, Brazil. His areas for research are organisational innovation, networks and organisational arrangements, models of governance and territorial development.

Anelise Rebelato Mozzato holds a Doctor's degree in Business Administration at the Unisinos University, Brazil. She is a Professor at the University of Passo Fundo, Brazil. Her areas for research are organisational and interorganisational learning, spatial agglomeration, organisational behaviour, human resource management, critical organisational studies and methods in qualitative research.

Karen Beltrame Becker Fritz holds a Doctor's degree in Rural Development at the UFRGS University, Brazil. She is a Professor at the University of Passo Fundo, Brazil. Her areas for research are development models, economic analysis of law and organisations, organisational networks and territorial development.

\section{Introduction}

This article discusses the inter-organisational relations (RIOs) maintained in productive agglomerations called as local productive arrangements (LPAs), analysing the extent to which the prevalence of characteristics of collaborative interdependence occurs. The field of research of this study is the LPA gems and jewels in the state of Rio Grande do Sul, Brazil, in the South of Brazil, emerging economies.

The theoretical foundations were developed within the scope of collective actions (Castells, 2000) that are part of the relational perspective of cooperation, in the relational vision of the strategy (Balestrin et al., 2014), offering a dynamic perspective resulting in relational gains (Dyer et al., 2018). Also, it is understood as necessary to consider the different aspects of the interrelation between the different actors of society, thinking about the local development that involves several dimensions, as Tenório (2007) affirms.

Increasingly, spatial agglomerations like LPAs are seen as advantageous alternatives, especially for small and medium-sized enterprises (Human and Provan, 1997; Cassiolato and Lastres, 2003; Todeva, 2006; Balestrin and Verschoore, 2008; Gronum et al., 2012; Verschoore et al., 2015). As Ibarra and Hansen (2011) point out, autonomous entities give way to collaborative actions, opening space for collaborative interdependence, in which the collective objective prevails (Nohria and Ecles, 1992; Rusbult and Kubacka, 2009; Ibarra and Hansen, 2011).

Thus, the relational vision gains strength, opposing the postulates of the dominant perspectives (Balestrin et al., 2014). Also, Dyer et al. (2018) and Adami et al. (2019) understand that such relational vision brings gains to those involved.

The relevance of the present study is justified because it identifies a research gap regarding collaborative interdependence. Most of the research focuses on the 
collaborative processes, not analysing the microprocessor, and also the impact of these in the development spaces, as in the LPAs. These spaces are understood as a form of territorial development around the economic, technological and production systems dynamics that operate in specific regions to promote the welfare of those involved.

Given the purpose and justification of the research in this brief introduction, the second part of the article brings forward assumptions related to LPAs and collaborative interdependence. Section 3 outlines methodological procedures. The fourth presents the LPA of gems and jewels of the RS and analyses the relations of collaborative interdependence in this one. Finally, the final research considerations and the references used are presented.

\section{LPAs and the importance of collaborative interdependence}

The productive agglomeration model of the LPA type is understood as a space for local and regional development that has as characteristics the participation of a given region in the allocation of its productive resources, the impacts of the global, political, administrative and economic policies on a certain territory; still, aspects linked to the capacity of social organisation for the transformation of their development possibilities (Cassiolato and Szapiro, 2003; Santos et al., 2007; Cassiolato et al., 2008; Redesist, 2017).

The study complements the 'classical' analysis of these spaces by focusing the RIOs within the LPAs. The interdependence collaborative approach is used which enables the analysis of collective attitudes and committed to the achievement of collective goals, showing the relations of exchange of information and reciprocal learning between the actors of productive arrangements analysed.

\subsection{Local productive arrangements}

Productive agglomerations refer to the idea of concentrating economic activities in a spatially limited area. Within these spaces of territorial governance and development among multiple approaches, at a greater, the concept of LPA derives from the approaches of Marshall and Porter.

For Marshall, in his classic study of English industries in the 19th century, in the so-called 'industrial districts' there is the formation of an industrial atmosphere where concentration favours the exchange of knowledge and innovations. In industrial districts, internal and external economies are the main sources of efficiency. The internal economies' need the internal resources of the companies individually, and also of the efficiency in the management with the increase of productivity. The 'external economies' refer to the company's competitive achievements in the market. An external economy becomes important as regards the competitive advantages obtained by small enterprises, due to the geographic proximity between the specialised companies, which thus guarantee a large scale production, presenting not only the reduction of transportation costs and in other transactions and enabling communication between companies (Marshall, 1985).

The industrial district represents in literature one of the main aspects of the relationship between economic activity and territory. This concept was rescued by several 
authors, at the beginning of the 1970s, to understand the dynamics and potential of new industrial agglomerations from the USA and Europe (Lemos, 2003). As a classic reference, for this theoretical approach are the studies on the industrial districts in (the so-called) third Italy, having a great division of labour and strong cooperation between companies. The model was based not only on the productive relationship between companies but also on a relationship with the government to achieve business success and social integration (Becattini, 1999).

A striking feature of the LPAs models of the Italian industrial districts is strong multilateral cooperative relations. The operation of this type of cooperation depends on local proximity, high level of trust and a high sense of community. The concept of LPA, having as the main paradigm the Italian industrial districts, emphasises the importance of the cooperation in the presence of small or medium-sized companies, spatially concentrated in some links of the productive arrangements (Santos et al., 2007). The LPAs can also be worked through models designed from the perspective of small network providers that operate in the hands of a large lead in the production arrangement. A classic example is the Silicon Valley region in North America (Pires et al., 2011).

In the 1990 Michael Porter coined a new concept on agglomerations called cluster. For Porter, cluster is a group geographically close to interconnected companies and associated institutions in a particular field, bound by common points and complementarities. Its geographical range varies from one region, a state or even a single city to embrace neighbours or neighbouring countries; is related to the distance that information, transactions, incentives, and other efficiencies occur (Porter, 2000).

In Brazil, the complexes were strongly induced by government policies from the 1950s onwards with the auto industry. However, it was in the 1970s that the policy of support to the complexes acquired its strongest and most finished form, focused mainly on the petrochemical sector, aiming at import substitution and increasing competitiveness outside Brazil (Santos et al., 2007). Brazil relied on concepts derived from the theory of industrial districts and clusters with studies of productive and innovation systems for the creation of the LPAs model.

In Brazil, the LPA terminology was introduced in the academic environment from the 1990s. This terminology has as one of the main references the network of researches in local productive and innovative systems (RedeSist) of the Federal University of Rio de Janeiro (Redesist, 2017).

There are many actors, within the LPAs that are related to the search and construction of common interests in the territory, which they belong. In this sense, the formation of different inter-organisational arrangements, like the LPAs, with cooperative relations as an advantageous alternative for micro, small and medium enterprises has been a recurrent discussion in the last three decades, both in the international literature and in the national literature (Human and Provan, 1997; Schmitz and Nadvi, 1999; Becattini, 1999; Cassiolato and Lastres, 2003; Cassiolato and Szapiro, 2003; Verschoore, 2004; Todeva, 2006; Santos et al., 2007; Balestrin and Verschoore, 2008; Zaheer et al., 2010; Gronum et al., 2012; Verschoore et al., 2015; Wegner et al., 2017). In this way, companies seek to achieve the objectives and obtain competitive advantages, which would likely be hindered in isolation. In this logic, LPAs are increasingly seen as a source of competitive advantage, especially for small and medium-sized enterprises. Empirical evidence is found in the Brazilian context (Wegner and Zonatto, 2016), as an emerging economy generating significant performance for the actors involved an advantage in the international markets, in the logic studied by Jalali (2017). 
Cassiolato et al. (2008) affirm that it is strategic to think of new policies that promote productive and innovative potentialities in Brazil, allowing the country to improve its bases of development. As Ibarra and Hansen (2011) point out, in collective strategies, the notion of autonomous entities gives way to cooperation for collaborative actions and, in this context, opens space for collaborative interdependence.

\subsection{Collaborative interdependence in the context of LPAS}

Collaborative interdependence requires collective and committed attitudes, with the collective goal prevailing (Nohria and Ecles, 1992; Rusbult and Kubacka, 2009). In this logic, collective goals are more important than personal goals.

Interdependence refers to the link between the different actors. According to Lubatkin et al. (2001) and Muthusamy and White (2005), interdependence can be of:

a objectives - interdependence of objectives, which are common among the different actors, showing convergent interests

b resources - interdependence of resources between the actors and refers to the sharing or combined use of resources, there being receptivity and exchanges due to the needs for the realisation of a specific business

c accomplishment of the tasks - interdependence between the actors in the accomplishment of joint tasks, being receptivity and exchanges to complement the tasks.

The interdependence of both objectives, resources, and complementarity in the accomplishment of tasks, reveals the reciprocal commitment existing between the partners of an LPA (Lubatkin et al., 2001; Muthusamy and White, 2005), thus consolidating collaborative interdependence.

Muthusamy and White (2005) discuss the mutuality of commitments, which induces the understanding of the interdependence between actors related in an inter-organisational configuration. In this way, responsible for increasing the possibilities of relationships, including providing a basis for meaningful communication and reducing uncertainties for the parties. The authors state that complementarity can occur at the level of information, resources, and tasks, demonstrating reciprocal commitment.

As reported by Lubeck et al. (2012), in the majority of cases of RIOs that show interdependence, the different actors direct their efforts towards a specific set of economic activities that culminate in positive externalities. In a similar sense, Wegner and Zonatto (2016) affirm that the participation of the different actors in the LPAs is fundamental for the creation of the interaction. Thus, by building a relationship of greater trust, which favours the exchange of information and the creation of collective knowledge. Thus, it can be said that this increases collaborative interdependence, which is positive for RIOs and the consolidation and development of LPAs.

Human and Provan (1997) explain that the cooperating companies carry out diverse activities of interdependence. Thus, timely activities in the interdependence of resources and the complementarity of tasks can make all the difference in business and for an LPA. Still, as Matos et al. (2015) point out, learning is fundamental for the improvement of procedures in the search for new skills, development, production and commercialisation 
of goods and services. Collaborative interdependence enables learning among different actors (Matos et al., 2015; Mozzato and Bitencourt, 2018).

Human and Provan (1997) point out that small and medium-sized companies, in collaborative attitudes, are more likely to achieve better results because of greater access to resources, friendship relationships and information exchanges that can be performed in complementarity or exchange of information and resources.

Although the notion of collaborative interdependence should be placed on a higher plane than that of competition, this is not always the case. Even knowing that the dominance of cooperation is necessary to exist commitment and gains to those involved, is not always so. Therefore, competition cannot be denied, even in collaborative relationships. It is in this logic that Nalebuff and Brandenburger (1996) coined the term 'competition'.

However, Muthusamy and White (2005) point out that, if there are scarcity and dependence, there may be coercion of companies with scarce resources, which is very negative for RIOs. Thus, collaborative interdependence is impaired.

As Human and Provan (1997) and Muthusamy and White (2005) point out, information is part of interdependence, and the partner needs to be receptive to them and learn, which positively influences the ability to absorb, culminating in the susceptibility to learning. In a similar vein, Lubatkin et al. (2001) argue that as trust is developed, each organisation is more willing to increase its commitment to partnership, learning to trust and learn. Thus, Mozzato and Bitencourt (2018) refer learning becomes fundamental for the improvement and development of those involved in RIOs.

Based on Bresser and Harl (1986), Bresser (1988) and Balestrin et al. (2014, p.50) point out that "collective strategies represent the need for organizations to promote cooperative actions to deal with their natural dynamic interdependencies, constituting a structure that may be deliberate to better deal with environmental instability." Still, Wegner et al. (2017) emphasise that collective and interdependence are important for implementing strategies in small business RIOs, even if not necessarily consensual.

\section{Methodological course}

The research is characterised as a case study (Yin, 2005), of a qualitative nature (Denzin and Lincoln, 2008; Flick, 2009; Yin, 2016). As a unit of analysis, the LPA of gems and jewels of Rio Grande do Sul was chosen, focusing on the collaborative interdependence that occurs through the RIOs established among the different LPA actors. These are social actors of this research, namely: companies of different sizes; informal ventures; class associations; suppliers and research and teaching centres and public agencies. There is a significant number of actors involved in the LPA, each of whom takes on a role in the dynamics, considering the development of the sector and the municipality. In the selection of the LPA, the recognition and importance of the LPA were also considered at the national and international levels which is considered one of the five main agglomerations of the sector in the country (AGDI, 2015).

The qualitative research was chosen based on the understanding of the RIOs in a more detailed way, considering the meanings and the situational characteristics, following the precepts of Denzin and Lincoln (2008) and Flick (2009). Flick (2009) 
points out that in this way one perceives the nature of a social phenomenon that involves humans and their intricate social relations in diverse environments.

This research is classified as exploratory, which is part of a larger research project for research in the chosen field. Moreover, it is considered as being exploratory because these results are part of longitudinal research. The initial exploratory research provides greater familiarity with both the field of research and the subject. However, at the moment the research was developed in two stages. The first stage was through visits to the field, contacting with various social actors more informally. Non-participant observation and unstructured interviews (22 actors) were used as a research technique. This phase lasted six months, after the contact made with Sindipedras (class association). In this class association, the responsible person indicated the other actors who were part of the LPA and formal and informal enterprises. Subsequently, in the second stage of the research, with a broader knowledge of the field, 40 semi-structured interviews were conducted with different actors who maintain inter-organisational relationships in the LPA. This phase lasted another six months. The choice was made for accessibility, for indications and contacts made in the first stage of the research. The script of the interview was developed to identify the existence of collaborative interdependence between the different actors that maintain RIOs in the LPA and the consequent impact on local development. The interviews were recorded and later transcribed. The number of interviews was defined by saturation, based on the perception of the repetition of content by different informants (Yin, 2005; Flick, 2009).

Non-participant observation and document exploration were also used as data collection techniques. Work was done on field notes throughout the research. As secondary data were used printed materials of industries, the technological centre, Senai and UPF; sites of Soledade, Sindipedras, UPF, Senai, Sebrae and IBGM; websites of federal government agencies: MCT, MME, MDIC, MTUR, DNPM and CPRM and representatives of the state government: SCT, EMC and AGDI; theses, dissertations, articles and books.

All the collected data were submitted to content analysis (Bardin, 2016; Mozzato and Grzybovski, 2011), seeking to identify in the respondents' speeches, in the field notes and in the documents researched, contents related to the previously defined categories of analysis. Content analysis was chosen because it is a refined qualitative data analysis technique that follows the necessary scientific rigor (not rigidity).

Thus, the three phases proposed for the content analysis were followed:

1 in the first phase the data were organised and performed the floating reading of them

2 in the second phase the analytical categories were defined

3 finally, in the third phase the interpretations and analyses were carried out according to the theory.

Collaborative interdependence was defined as an analytical category. It was subdivided into three subcategories: shared goals, common resources, and task complementarity.

Multiple sources of empirical evidence were used to triangulate the data at the moment of data analysis, aiming for greater quality and greater reliability in the research, and by following the research outlines proposed by Yin $(2005,2016)$ and Flick (2009). 


\section{The LPA of gems and jewellery of Rio Grande do Sul: relational analysis}

\subsection{Characterisation of the LPA of gems and jewels of Rio Grande do Sul}

In the state of Rio Grande Sul in Brazil, there are 28 LPAs, in the most distinct areas. Among the state's LPAs, LPA gems and jewels occupy a prominent place in the processing and marketing segment. It is in the central area of the state of Rio Grande do Sul, in the region of Corede Alto da Serra do Botucaraí (Figure 1). The population, in 2015, was 104,609 inhabitants and the area of coverage of $5,762 \mathrm{~km}^{2}$, with a housing density of $18.1 \mathrm{~km}^{2}$ (Fee, 2016).

Figure 1 Location map of the main cities of the LPA of gems and jewels of RS (see online version for colours)

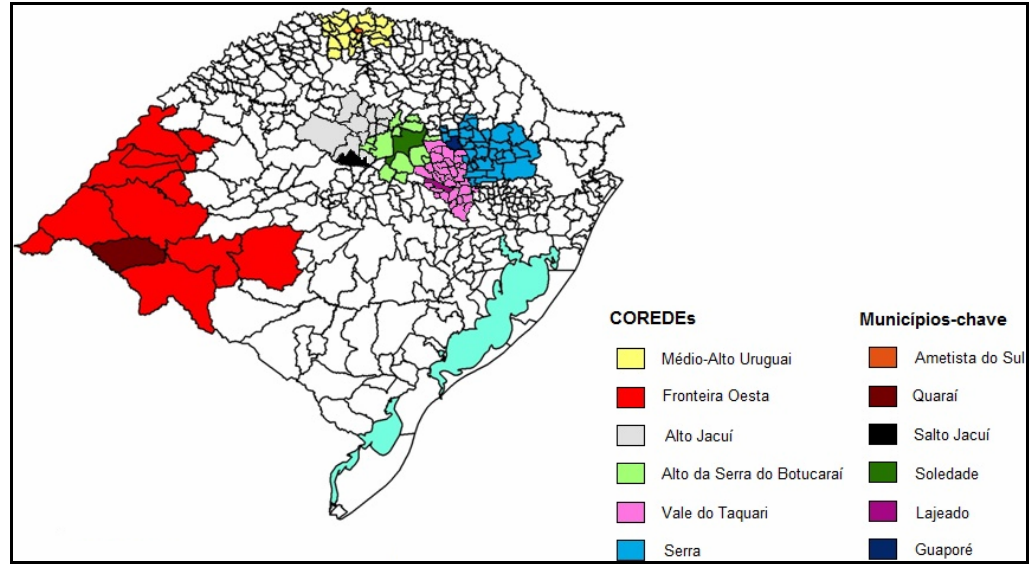

Source: Batisti and Tatsch (2012)

The LPA of gems and jewels is considered one of the five main agglomerates of the sector in the country, involving all the chain of production of this, from the activities of the mineral extraction, in the deposits in the state of Rio Grande do Sul, until the production and marketing of the final product; is also a reference in the regions where it is by its potential exporting and employment source (AGDI, 2015). In this LPA there are:

"The involvement of the mineral extraction activities, in the existing deposits in the state, until the production and the commercialization of the final product crude stones, stoned gems, stone handicrafts, jewelry, veneers, and costume jewelry. It is also notable for its export potential and as an important source of employment in the regions where it is located." [AGDI, (2014), p.15]

Regarding mineral processing and stone artefacts, small firms and informal 'back yard' factories are largely responsible for stone industrialisation activities - such as polishing, hammering, dyeing, stonecutting, among others. The largest companies (exporters mentioned above), most, act as marketing centres, buying the raw material (Brazilian and 
imported stones), outsourcing practically all the processes of industrialisation of the gems and, finally, selling the products in large showrooms (for the retail and the wholesale) or through export actors.

The companies in this segment, especially stoning, still produce without proper standardisation, offering their products at non-competitive prices. One cause for such inadequacies is the use of lagged technology in this production process, which generates a situation in which the jewellery industry in the Rio Grande do Sul avoids the use of stones in their pieces, or acquires gems calibrated from other states or countries (Batisti, 2009; Tatsch, 2009; Batisti and Tatsch, 2012).

An LPA is closely linked to economic, social and political situations involving relationships between many parties, which create collaborative interdependence. This requires collective attitudes and goals, as stated by Nohria and Eccles (1992) and Rusbult and Kubacka (2009), as they do in many actions in the LPA of gems and jewels of the South of Brazil ${ }^{1}$.

The LPA brings together several and diversified actors that have maintained inter-organisational relationships for many years, undergoing constant transformations due to the necessary adaptation and desired prospecting, signalling a certain degree of maturity in the relations established between them. In the logic outlined by Human and Provan (1997), Todeva (2006), Santos et al. (2007), Balestrin and Verschoore (2008), Zaheer et al. (2010), Gronum et al. (2012), Verschoore et al. (2015) and Wegner et al. (2017) this LPA is increasingly perceived as a source of competitive advantage, especially for small and medium-sized enterprises.

Some of the different actors that make up the LPA are mentioned: companies of varying sizes, prevailing those of micro-size, Sindipedras, AproSol, technological centre of gems, stones and jewels of Rio Grande do Sul - CTPedras, Senai, Sebrae, universities (UPF, UFGS, UNIVATES, UFSM), sales agents, APPSol, Acis, suppliers of machinery and equipment, stones mining, cooperatives, federal, state and municipal government, financial institutions and clients.

The relevance of the city of Soledade, as an important part of the local economy, was verified in the LPA surveyed, accounting for most of the region's exports, and being the main stoning and commercialisation centre in RS. Soledade concentrates many of LPA's collaborative activities, such as Soledade gem and mineral fair, better known in Brazil as ExpoSol (in its 18th edition in 2018).

Therefore, the LPA of gems and jewels of the RS comprises different economic, political and social actors, represented by companies, informal enterprises, class associations, research and teaching centres, advisories and consultants, public agencies, suppliers and clients, following the logic presented by Cassiolato and Lastres (2003) and also by Redesist (2017). A significant number of actors are involved, each of which assumes a role in the dynamics of LPA, aiming at their interests, developing the sector and the city.

Given the initial exploration of the field of research, advances are made to seek broader knowledge of LPA by obtaining its procedural vision, focusing on RIOs and, especially, on collaborative interdependence. It begins by exposing the more structural aspects of the horizontal relationships established between the different actors in the LPA through Figure 2. 
Figure 2 The flow of relations between the actors involved in the LPA of gems and jewels-RS (see online version for colours)

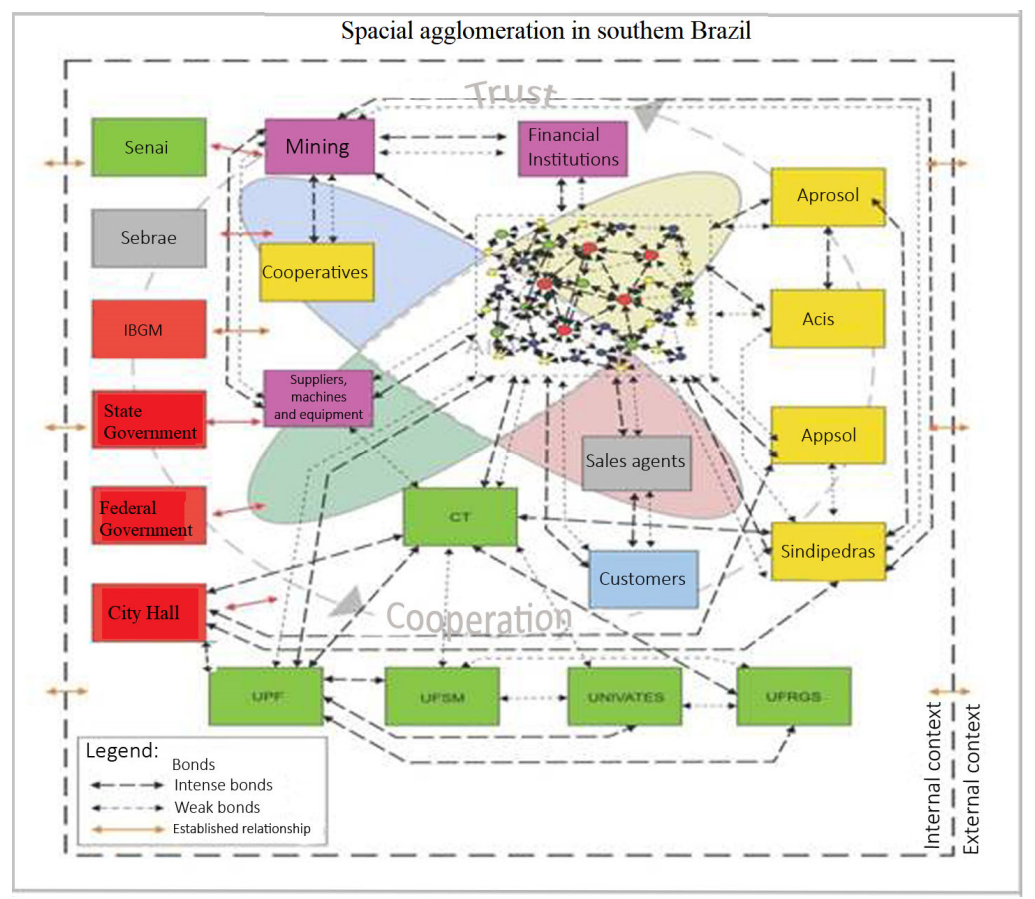

Source: Mozzato and Bitencourt (2018, p.187)

Observing Figure 2, as already pointed out by Mozzato and Bitencourt (2018), it is evidenced that the LPA is configured in an environment of multiple relationships, with an interrelation between the majority of actors, both through intense links with weaker links. It is evident that, like any other LPA, apart from the relations and characteristics of the internal context (cultural, historical and political), it is also closely related to the external context, suffering its influences.

Regarding the internal context, the interference of cultural, historical, social, economic and political context in the dynamics of LPA is undeniable, both being influenced and influencing. There is the coexistence between the owners of people who extract the stones (owners of the lands where the minerals are located), the miners (through cooperatives), companies that benefit the stones and manufacture artefacts, besides the exporting companies that act in the domestic market and the external market. Exporters have a strong influence on the local production structure, especially as regards the price paid for the material extracted (Batisti and Tatsch, 2012).

About the supply of raw materials and inputs, some observed that many companies are offering in the LPA. The firms that benefit the stones provide, for example, sawed stones for others that produce stone artefacts and stoned stones for companies that 
produce jewellery. A perceived bottleneck in the supply of raw materials refers to the absence in Guaporé and the region of companies supplying precious metals (gold and silver) and non-precious metals (brass, zamac, lead, and tin) for the casting of the parts. However, many firms offer 'raw' products (made from non-precious metals), ready to be bathed. These 'raw' products can be produced by LPA's own companies or bought for resale from other states (the Limeira arrangement in São Paulo is a good example) or from other countries (such as China, mainly) (Batisti, 2009; Tatsch, 2009; Batisti and Tatsch, 2012).

\subsection{Collaborative interdependence relations: importance for the LPA researched}

The LPA configures itself as indeed an arrangement regarding the characteristics necessary for both. However, it should be noted that a recent study by Fee (2015) coordinated by Costa and Jornada $(2015$, p.46) points to a worrying situation regarding factors that hinder collaboration between LPA companies:

\footnotetext{
"It is an LPA in which there are external Marshallian economies and relations of articulation and cooperation among local actors. However, it should be noted that, although these relations between local institutions and those with companies are positive, the latter, and the articulation and cooperation by associative, are hampered by fierce competition in product prices, in a context of high informality that entails unfair competition between legalized and non-legalized enterprises."
}

According to the above, one can not deny the asymmetry in the relations between the different actors in the LPA studied, even if there is collaborative interdependence. It can be argued that producers of jewels, veneers and costume jewels, the smaller and less time-consuming industries in the market, and the more traditional, share their goals, precisely because they are pairs, forming subgroups with very similar interests. However, this can not be generalised to the LPA given the asymmetry evidenced. Shared goals are confirmed between most of the different actors in LPA, and increasing understanding of the need for greater sharing so personal goals can be reached more easily. These findings are in line with the research findings of Lane and Lubatkin (1998) when they say that awareness of the need for cooperative work helps to achieve personal goals. Thus, everyone involved gets the most fruitful results.

We can see the differentiation between the largest and the smallest industrialists. However, the understanding is that it is part of the market dynamics. These issues were already understood as exploitation, even because there was a more intense relationship of dependence. Today, the view is more towards natural interdependence, as confirmatory statements from various actors: "power is symmetrical, only the great is great and the small, small, we have to know that"; "certainly the greater have more power, this is the law of the market, but I do not perceive exploitation, only a condition, a conquered condition."

It is worth mentioning the coexistence between cooperation and competition, the 'coopetition' mentioned by Nalebuff and Brandenburger (1996), which is reported by practically all the LPA interviewees and can be seen in two lines that follow: "competition and collaboration appear together, providing learning nonetheless ... There 
is a spirit of sharing, but very carefully, without much openness 'and' there is competition in collaborative processes, which is normal in any industry."

The different actors perceive gains by working collaboratively; however, collaborative attitudes are more punctual, being related to exports, exchange or loan of goods and complementarity of tasks (e.g., the smaller ones benefit the stones for the larger ones, the smaller ones lapidate stones for jewellery manufacturers). Muthusamy and White (2005) point out that, according to these same authors, the reciprocal commitment is one of complementarity both at the information level and in the resources and tasks.

In these activities of interdependence, inter-organisational learning is a result, enabling learning among different actors, as Mozzato and Bitencourt (2018) states. Both Matos et al. (2015) and Mozzato and Bitencourt (2018) argue that learning is fundamental for the improvement and development of those involved in RIOs. Follows illustrative evidence: "I'm only where I am because I learned from others right here in our APL, I would not have perfected the products had it not been for such opportunities of learning" (formal enterprise).

Collaborative interdependence is identified as specific activities, is considered fundamental to LPA, which is in line with what Cassiolato and Lastres (2003), Balestrin and Verschoore (2008) and Zaheer et al. (2010) report on the importance of collaborative strategies to improve organisational performance.

Besides the asymmetric and competition issues, when reflecting on the reality of the empirical field, some observe that certain members of the LPA barriers, which hinder their relationship with others. Consequently, some of these barriers are cognitive (sociocultural issues) and other emotional (affections, dislikes, rivalries, family and friendship relationships), hindering their relationships and, collaborative interdependence. In this sense, as Human and Provan (1997) point out, although friendship relationships instigate collaborative attitudes, they sometimes occur in subgroups, which maintains greater emotional closeness.

In the analysis of the different empirical pieces of evidence, the interdependence among the LPA actors of gems and jewels is confirmed, which is achieved through shared objectives, common resources, and complementarity of tasks, as pointed out by Lubatkin et al. (2001) and Muthusamy and White (2005). It can be inferred the incidence of reciprocal commitments between the partners, which are defended by Lubtkin et al. (2001) as important. Following the same logic, but advancing in the research, Muthusamy and White (2005) discuss the mutuality of commitments, which induces the understanding of the interdependence between actors related in an inter-organisational configuration.

It is observed sharing objectives and resources and the complementarity of the tasks between the representations of the LPA and the majority of the companies and enterprises. It is evidenced that most of the different LPA actors share goals and few do not share resources and tasks. However, there is an understanding of the need for greater collaborative interdependence so personal goals can be achieved more easily as is achieved by the similarities in the results of the research carried out by Lane and Lubatkin (1998). In which they stated that awareness of the need for work cooperative helps in the achievement of personal goals and all involved, obtaining more fruitful results. 
Table 1 Collaborative interdependence in the empirical field

\begin{tabular}{|c|c|}
\hline $\begin{array}{l}\text { Collaborative } \\
\text { interdependence }\end{array}$ & Collaborative actions \\
\hline \multirow[t]{2}{*}{ Shared goals } & $\begin{array}{l}\text { Convergent interests among most of the } \\
\text { different actors. }\end{array}$ \\
\hline & $\begin{array}{l}\text { Examples of actions with convergent } \\
\text { interests: meetings promoted by diverse } \\
\text { representations, governance, } \\
\text { performing CTPedras, APPSol, } \\
\text { AproSol, city hall, Sebrae, Senai, } \\
\text { Sindipedras, Acis and universities, } \\
\text { relations between cooperatives and } \\
\text { people who extract the stones, between } \\
\text { suppliers of machinery and equipment } \\
\text { and people who extract stones. }\end{array}$ \\
\hline
\end{tabular}

Common There is resource interdependence resources among LPA actors.

Example of common resources: exchange and loan of raw material or merchandise, sales of raw material or products among the industry, use of equipment and technologies of CTPedras.

Complementarity of tasks
Complementarity of tasks between the actors occurs.
Depositions

"The partnerships established with entities and other organizations interested in the development and leverage of the sector enable the development of joint actions for the growth of the sector.'

"There are values, common goals, and interests, shared perception, etc.... It is precise because of this that we carry out joint tasks, exports, an organization for fair participation and other things."

"Almost everyone depends on everybody. If I need some stone benefit, as I do not benefit or do not have that stone, I search with one of my partners."

"CTPedras helps us a lot, every base of the rings I make there; they have the machines."

"When I have to lapidate a lot of the same stone for a client, even if I do not have it in sufficient quantity, I say that I have... Later I'll handle it; I'll look for, there's always someone whom I can buy from or borrow from."

"The joint sale is made more to meet the needs of our customers because our company can export alone, filling containers, but the smaller ones do not."

Examples of complementarity of tasks: exports, outsourcing, Exposol, participation in fairs, missions, joint marketing. The different LPA representations also act in the complementarity of tasks, for example: the work of sales agents, CTPedras, Sebrae, Senai and universities, the work of suppliers of machinery and equipment that meet the needs of the sector, the participation of the city, APPSol, Sindipedras, AproSol and Acis, stones mining and cooperatives.
"Gradually industries are moving in the direction of not doing everything individually, of realising that one can complement the work of the other."

"What exists is the joint marketing activity, mainly through Exposol."

"The partnerships established with entities and other organisations interested in the development and leverage of the sector enable the development of joint actions for the growth of the sector." 
It is also evidenced that the collaborative interaction occurs more in the complementarity of the tasks. Virtually all the actors talk about joint exports that occur in a well organised and quiet manner, besides the recurrent practice of outsourcing that has prompted the opening of several smaller companies and enterprises. Most business owners understand how a good acting market, not realising exploitation, yet admit the pressure when negotiating prices of products with the larger ones. Some observe that the sector has been organising in the sense that the smaller companies and enterprises seek some differential, trying to minimise competition; however, it can not be denied.

According to Lubatkin et al. (2001), the different actors understand better the importance of collective activities, realising that they are more positively performed collaboratively than individually. Such understanding seems to gradually increase among the different actors that make up the LPA.

Actors in an interdependent relationship of objectives are more likely to share resources and work on the complementarity of tasks, which is confirmed in the LPA of gems and jewels. Such a casual relationship is defended by authors like Lubatkin et al. (2001) and Muthusamy and White (2005). Also, Becattini (1999), Gurizatti (1999) and Shima (2006) emphasise the importance of sharing resources to increase the competitiveness of each organisation.

However, in the case of scarcity and dependence, Muthusamy and White (2005) warn that there may be coercion of companies with scarce resources, which is very negative for RIOs. Based on the pieces of evidence of the research in the LPA researched, it is impossible to affirm the inexistence of such situation mentioned by the authors. The intense and significant relationship between companies and enterprises of different sizes is noticeable, and many of these companies and smaller enterprises depend on the labour demand of the larger ones, which specialise in a part of the processor in a product specifically.

Another worrying point is the competition strategies pursued by LPA companies that are cost-advantage-like. This means that local companies are striving to reduce costs to gain competitiveness in the supply of products at lower prices. Such evidence corroborates a recent study developed by Costa and Jornada (2015), which point to this situation as a concern. Therefore, one can not deny the asymmetry in the relations between the different actors in the LPA studied. In the perspective of cost reduction, because the greater demand in the LPA of gems and jewels is for products of low complexity, together with the difficulties, makes that most companies put in a comfortable position concerning the realisation of investments in the production and improvement of products.

However, there is a certain level of collaborative interdependence in LPA researched, and it stresses the importance of the same for developing LPA in generating benefits of economic, social, personal, community, cooperative, reciprocity between others. In a strategy linked to a development space with a governance model these characteristics, when exercised, lead to developing LPA that translates well beyond the advantages of Marshall's external economies or Porter's competitive advantages. It is part of the joint construction of the local actors with their resources, links and institutions aiming beyond the competitiveness, the social and cultural well-being of the community living in that environment (Brandão, 2007; Pires et al., 2011; Siedenberg, 2012). It is concluded that the relational vision gains strength, bringing gains to those involved in the collaborative relations, as pointed out by Balestrin et al. (2014), Dyer et al. (2018) and Adami et al. (2019). 


\section{Final considerations}

At the end of this research, with theoretical and empirical evidence the importance of the collaborative interdependence between the different actors that compose an LPA is perceived. As a result, it should be noted there are relationships of collaborative interdependence in the LPA of gems and jewels of RS, which could be verified in actions related to shared objectives, use of common resources and complementarity of tasks, in the sense highlighted by Lubatkin et al. (2001) and Muthusamy and White (2005). However, it can not be denied that collaborative actions could be more effective, encompassing the LPA as a whole.

In particular, this logic the LPA can contribute to the local development as reported by Lubeck et al. (2012), RIOs that show interdependence, direct efforts towards a specific set of economic activities that culminate in positive externalities. Thus, considering what Lastres and Cassiolato (2003) postulate, this LPA presents relations of interdependence in the RIOs established between the different actors. These relationships are of articulation and consistent links, forming an important organisational architecture that continually transforms the business context, the place in which it is inserted.

Through the collaborative interaction in the LPAs, taking collective actions (Castells, 2000) meets the relational vision of the strategy defended by Balestrin et al. (2014), which fosters greater gains, reduces costs, confidence and reduce opportunism. In this way, it is possible to promote local development in the manner recommended by Tenório (2007), involving several dimensions, not only the economic one. Empirical evidence is found that generates advantages to those involved in this Brazilian APL, according to Wegner and Zonatto (2016) and Jalali (2017).

At the end of this article, we mean to be contributing to the debate about the importance of collaborative interdependence (micro processes analysis), above all for the advances of the actors in RIOs that are part of the LPAs, and for local development. The debate on the relationship between collaborative interdependence, developing LPAs and local development is presented as a suggestion for future research. In this way, you are making possible the expansion of studies in this subject.

\section{References}

Adami, V.S., Verschoore, J.R. and Antunes Jr., J.A.V. (2019) 'Effect of relational characteristics on management of wind farm interorganizational construction projects', Journal of Construction Engineering and Management, Vol. 145, No. 3, p.05018019.

Agência Gaúcha de Desenvolvimento e Promoção de Investimento (AGDI) (2015) Plano de Desenvolvimento com Metodologia Participativa LPA Pedras, Gemas e Joias [online] http://www.agdi.rs.gov.br (accessed July 2015).

Balestrin, A. and Verschoore, J. (2008) Redes de cooperação empresarial: estratégias de gestão na nova economia, Bookman, Porto Alegre.

Balestrin, A., Verschoore, J.R. and Perucia, A. (2014) 'A visão relacional da estratégia: evidências empíricas em redes de cooperação empresarial', BASE - Revista de Administração e Contabilidade da Unisinos, Vol. 11, No. 1, pp.47-58.

Bardin, L. (2016) Análise de conteúdo, Edições 70, São Paulo. 
Batisti, V.S. (2009) Politicas para aglomerados produtivos: uma análise do arranjo produtivo local de gemas e joias do Estado do Rio Grande do Sul, Dissertação de mestrado em Economia, Centro de Ciências Econômicas, Universidade do Vale do Rio dos Sinos, São Leopoldo, RS, Brasil.

Batisti, V.S. and Tatsch, A.L. (2012) 'O arranjo produtivo local (LPA) gaúcho de gemas e joias: estruturas produtiva e comercial, arranjos institucional educacional e relações interorganizacionais', Ensaios FEE, Vol. 33, No. 2, pp.513-538.

Becattini, G. (1999) 'Le district marshallien: une notion socio-économique - organization industrielle et croissance urbaine', in Benko, G. and Lipietz, A. (Eds.): Les Régions Qui Gagnent - districts et réseaux: les nouveaux paradigms de la géographie économique, Presses Universitaires de France, Paris.

Brandão, C. (2007) Território e Desenvolvimento: as múltiplas escalas entre o local e o global, Unicamp, Campinas.

Bresser, R. (1988) 'Matching collective and competitive strategies', Strategic Management Journal, Vol. 9, No. 4, pp.375-385, https://doi.org/10.1002/smj.4250090407

Bresser, R.K. and Harl, J.E. (1986) 'Collective strategy: vice or virtue?', Academy of Management Review, Vol. 11, No. 2, https://doi.org/10.5465/amr.1986.4283447.

Cassiolato, J.E. and Lastres, H.M.M. (2003) 'O foco em arranjos produtivos e inovativos locais de micro e pequenas empresas', in Lastres, H.M.M., Cassiolato, J.E. and Maciel, M.L. (Eds.): Pequena Empresa: Cooperação e Desenvolvimento Local, RelumeDumará, São Paulo.

Cassiolato, J.E. and Szapiro, M. (2003) 'Uma caracterização de arranjos produtivos locais de micro e pequenas empresa', in Lastres, H.M.M., Cassiolato, J.E. and Maciel, M.L. (Eds.): Pequena empresa: cooperação e desenvolvimento local, Relume Dumará, São Paulo.

Cassiolato, J.E., Lastres, H.M.M. and Stallivieri, F. (2008) Arranjos produtivos locais: uma alternativa para o desenvolvimento, E-Papers, Rio de Janeiro.

Castells, M. (2000) 'Toward a sociology of the network society', Contemporary Sociology, Vol. 29, No. 5, pp.693-699.

Costa, R.M. and Jornada, M.I.H. (2015) Arranjo Produtivo de Pedras, Gemas e Joias do Alto da Serra do Botucaraí. Relatório II, FEE. Relatório do Projeto Estudo de Aglomerações Industriais e Agroindustriais no RS, Porto Alegre [online] http://www.fee.rs.gov.br/ publicacoes/relatorios (accessed May 2015).

Denzin, N.K. and Lincoln, Y.S. (2008) Collecting and Interpreting Qualitative Materials, Sage, Los Angeles.

Dyer, J.H., Singh, H. and Hesterly, W.S. (2018) 'The relational view revisited: a dynamic perspective on value creation and value capture', Strategic Management Journal, Vol. 39, No. 12, pp.3140-3162 [online] https://doi.org/10.1002/smj.2785.

Flick, U. (2009) Introdução à pesquisa qualitative, Translated by Costa J.E., 3rd ed., Artmed, São Paulo.

Fundação De Economia E Estatística Siegfried Emanuel Heuser (FEE) (2016) População [online] http://www.fee.rs.gov.br/perfil-socioeconomico/coredes/detalhe/?corede=Alto+da+Serra + do + Botucara\%ED (accessed May 2016).

Gronum, S., Verreynne, M.L. and Kastelle, T. (2012) 'The role of networks in small and medium-sized enterprise innovation and firm performance', Journal of Small Business Management, Vol. 50, No. 2, pp.257-282.

Gurizatti, P. (1999) 'O nordeste italiano: nascimento de um novo modelo de organização', in Urani, A. et al. (Eds.): Empresários e empregos nos novos territórios produtivos: o caso da Terceira Itália, DP\&A, Rio de Janeiro.

Human, S.E. and Provan, K.G. (1997) 'An emergent theory of structure and outcomes in small-firm strategic manufacturing networks', Academy of Management Journal, Vol. 40, No. 2, pp.368-403.

Ibarra, H. and Hansen, M.T. (2011) 'Are you a collaborative leader?', Harvard Business Review, Vol. 89, Nos. 7-8, pp.68-74. 
Jalali, S.H. (2017) 'How alliance partner characteristics can affect performance? An empirical evidence from emerging economies context', International Journal of Strategic Business Alliances, Vol. 6, Nos. 1-2, pp.1-17, DOI: 10.1504/IJSBA.2017.089837.

Lane, P.J. and Lubatkin, M. (1998) 'Relative absorptive capacity and interorganizational learning', Strategic Management Journal, Vol. 19, No. 5, pp.461-477.

Lemos, C. (2003) Micro, Pequenas e Médias Empresas no Brasil: Novos Requerimentos de Politicas para a Promoção de Sistemas Produtivos Locais, IE/UFRJ, Tese de Doutorado [online] http://www.ie.ufrj.br/redesist (accessed 21 April 2015).

Lubatkin, M., Florin, J. and Lane, P. (2001) 'Learning together and apart: a model of reciprocal interfirm learning', Human Relations, Vol. 54, No. 10, pp.1353-1382.

Lubeck, R.M., Wittmann, M.L. and Silva, M.S. (2012) 'Afinal, quais variáveis caracterizam a existência de cluster Arranjos Produtivos Locais (LPAS) e dos Sistemas Locais de Produção e Inovação (SLPIS)?', Revista Ibero-Americana de Estratégia, Vol. 11, No. 1, pp.120-151.

Marshall, A. (1985) Princípios de Economia: tratados introdutório, 2nd ed., Vol. 1, Nova Cultural, São Paulo.

Matos, M.G.P., Borin, E., Cassiolato, J.E. and Arruda, D.A. (2015) 'Evolução de Arranjos Produtivos Locais em uma década', in Matos, M.G.P., Borin, E. and Cassiolato, J.E. (Eds.): Uma década de evolução dos arranjos produtivos locais/organização, E-Papers, Rio de Janeiro.

Mozzato, A.R. and Bitencourt, C.C. (2018) 'The process of interorganisational learning in the context of spatial agglomeration', International Journal of Innovation and Learning, Vol. 24, No. 2, pp.176-199.

Mozzato, A.R. and Grzyboviski, D. (2011) 'Análise de conteúdo como técnica de análise de dados qualitativos no campo da Administração: potencial e desafios', RAC, Vol. 15, No. 4, pp.731-747.

Muthusamy, S.K. and White, M.A. (2005) 'Learning and knowledge transfer in strategic alliances: a social exchange view', Organization Studies, Vol. 26, No. 3, pp.415-441.

Nalebuff, B.J. and Brandenburger, A.M. (1996) Co-opetição, Rocco, Rio de Janeiro.

Nohria, N. and Eccles, R. (1992) Networks and Organizations: Structure, Form and Action, Harvard Business School, Boston.

Pires, E.L.S., Fuin, L.L., Mancini, R.F. and Neto, D.P. (2011) Governança territorial: Conceito, fatos e modalidades, Unesp-IGCE-Programa de pós-graduação em Geografia, Rio Claro.

Porter, M.E. (2000) 'Location, competition, and economic development: local clusters in a global economy’, Economic Development Quarterly, Vol. 14, No. 1, pp.15-20.

Redesist (2017) Rede de Pesquisa em Sistemas Produtivos e Inovativos Locais [online] http://www.redesist.ie.ufrj.br (accessed 12 April 2018).

Rusbult, C. and Kubacka, K. (2009) 'Interdependence theory', in Reis, H. and Sprecher, S. (Eds.): Encyclopedia of Human Relationships, pp.868-871, Sage, Thousand Oaks.

Santos, G.A., Diniz, E.J. and Barboza, E.K. (2007) 'Aglomerações, Arranjos Produtivos Locais e Vantagens Competitivas Locacionais', in Arranjos produtivos locais e desenvolvimentos, BNDES, Brasília.

Schmitz, H. and Nadvi, K. (1999) 'Clustering and industrialization: introduction', World Development, Vol. 27, No. 9, pp.1503-1514, Oxford.

Shima, W.T. (2006) 'Economia de redes e inovação', in Pelaez, V. and Szmrecsányi, T. (Eds.): Economia da Inovação Tecnológica, HUCITEC/Ordem dos Economistas do Brasil, São Paulo.

Siedenberg, R.D. (2012) Desenvolvimento sob múltiplos olhares, Unijui, Ijuí.

Tatsch, A.L. (2009) Relatório Final: Síntese dos Resultados, Conclusões e Recomendações Rio Grande do Sul, BNDES, Rio de Janeiro [online] http://www.politicaLPAs.redesist.ie. ufrj.br/ (accessed 20 May 2016).

Tenório, F.G. (2007) Cidadania e desenvolvimento local, FGV, Rio de Janeiro. 
Todeva, E. (2006) Business Networks: Strategy and Structure, Routledge, London.

Verschoore, J.R., Wegner, D. and Balestrin, A. (2015) 'The evolution of collaborative practices in small-firm networks: a qualitative analysis of four Brazilian cases', International Journal Management Practice, Vol. 8, No. 2, pp.152-168.

Verschoore, J.R.S. (2004) 'Redes de cooperação: concepções teóricas e verificações empíricas', in Verschoore, J.S. (Ed.): Redes de cooperação: Uma nova organização de pequenas e médias empresas no Rio Grande do Sul, pp.15-46, FEE, Porto Alegre.

Wegner, D. and Zonatto, P.A.F. (2016) 'Small-firm networks and strategies for consolidation: evidence from the Brazilian context', RBGN - Revista Brasileira de Gestão de Negócios, Vol. 18, No. 62, pp.525-544.

Wegner, D., Zarpelon, F.M., Verschoore, J.R. and Balestrin, A. (2017) 'Management practices of small-firm networks and the performance of member firms', Business: Theory and Practice, Vol. 18, No. 2, pp.197-207.

Yin, R.K. (2005) Estudo de caso: planejamento e métodos, Bookman, Porto Alegre.

Yin, R.K. (2016) Pesquisa qualitativa do início ao fim, Translated by Bueno D., Penso, Porto Alegre.

Zaheer, A., Gözübüyük, R. and Milanov, H. (2010) 'It's the connections: the network perspective in the interorganizational research', Academy of Management Perspectives, Vol. 24, No. 1, pp.62-77. 